\title{
Health Service Model of Community Health Center in Implementing National Health Insurance Program
}

\author{
Amirul Mustofa ${ }^{1}$, Sri Roekminiati ${ }^{2}$, and Damajanti Sri Lestari ${ }^{3}$ \\ \{amirul.mustofa@unitomo.ac.id\} \\ Pogram Study of Public Administrative Science ${ }^{1,2}$, Pogram Study of Bisnis Administrative Science ${ }^{3}$ \\ Faculty of Administrative Science - Dr. Soetomo University \\ Surabaya, Indonesia
}

\begin{abstract}
The purpose of this study is to formulate an effective health service model in order to improve services carried out by Community Health Center (CHC), especially in implementing the National Health Insurance (NHI) program. This is necessary, because the CHC has not been able to carry out the service function optimally, especially to carry out the First Level Health Facilitation (FLHF) function. The theories used in this study include: public service, health services, and local wisdom. The research method used is qualitative research with interactive model data analysis techniques. The results showed: first, health services carried out by CHC at Batu - Batu City and CHC at northern Ponorogo - Ponorogo District, still use conventional health service models ranging from registration to health checks to various types of diseases. Health examination services have not been divided according to the type of disease suffered by the patient; and secondly, health services carried out by the CHC at Medokan Ayu - Surabaya City show better quality services, because starting registration, the service model has been divided into various types of health services. Patients after registering, then patients go to the room or poly provided according to the type of disease suffered by the patient.
\end{abstract}

Keywords: Health Services, Community Health Center, and National Health Insurance

\section{Introduction}

The policy of the NHI program that was implemented 5 years ago still faces various kinds of obstacles. One of the obstacles encountered in the field is access to services at the $\mathrm{CHC}$ as a FLHF and in hospitals, among which is a lack of health workers. Until 2015, the shortage of specialists was 9,389 people, general practitioners 33,773 people, assistant pharmacists 6,381 people, sanitarian 10,687 people, nutrition 13,725 people, physical fitness 4,107 people (http://www. slideshare.net/daninjaya /analisa-tantangan-dan-hambatan pelaksanaan-jkn, accessed January 5, 2016).

Various studies in the last three years have shown that the substance of the study is related to: (i) the visit of Surabaya residents on the NHI program service website, is very high, so that all NHI service products can be understood [1] (ii). The management of funds resulting from the claim of the NHI program has not been optimally used, even the payment of the claim results is still not in accordance with what was proposed [2 ]; and (iii) the service of the NHI program at the CHC in Surabaya is still not implemented optimally, because of the limited medical personnel and facilities prepared [3]. 
Referring to the study, that in order to improve the quality of service of CHC as FLHF, it is felt necessary to formulate a service model that pays attention to local wisdom in health services. In addition, this study seeks to formulate models that are important for improving the performance of institutional $\mathrm{CHC}$ and national apparatuses with a governance approach. Therefore, the state of art of this study is "a service model for patients with NHI program based on local wisdom in CHC as FLHF". By formulating this model, it is expected that CHC services will increase with a variety of superior services in providing public health services.

Public services are organized by public employees, because basically a government is established to provide services to the community, so that prosperity can be realized for the community. Thus, that public service is a service organized by government institutions, which is not profit-oriented. The term public in the services provided by the government is very specific and must be interpreted with great care. Public meaning in public service is not the same as the customer. The author agrees that the statements of Denhardt and Denhardt which criticizes the understanding of the New Public Management paradigm which is principled that "run government like a business" or "market as a solution to the public sector" [4].

Treating services to citizens is very different from treating customers. Service to citizens not only secretaries provides satisfaction, but more emphasis is on how to give citizens the right to get public services. The government, as a public service provider, must work continuously to find service innovations for citizens so that the services provided will be of high quality. Various studies of public services, have found different results from one another, due to services held by the government that are "not profit oriented" and to improve the quality of public services, "organizing services must be motivated in a very different way" [5]. There was also found a "tendency for salary reduction for public sector employees when attending education. Even public sector employees lack attention and job security, while carrying out service duties [6].

At present, various government innovations in providing public services include collaborating with the private sector in the provision and implementation of public affairs. Through this endeavor, it is hoped that it will be able to answer issues related to the understanding of the public, the public interest, and how the public interest can be realized without being dependent on government institutions. Government efforts to collaborate with other parties have referred to the concept of governance. In the governance concept the responsibility for providing public goods and organizing public affairs is the responsibility of three actors, namely: the state, the private sector and civil society. Thus, according to the concept of Governance that the government is no longer believed to be the only actor capable of efficiently, economically and fairly providing various forms of public services. Therefore, this governance concept views the importance of partnership and networking among stakeholders in the implementation of public affairs.

Various service gaps are often found in service delivery to improve quality services, as stated by Zeithaml and Berry quoted by Shahin in figure 1. [7]: 


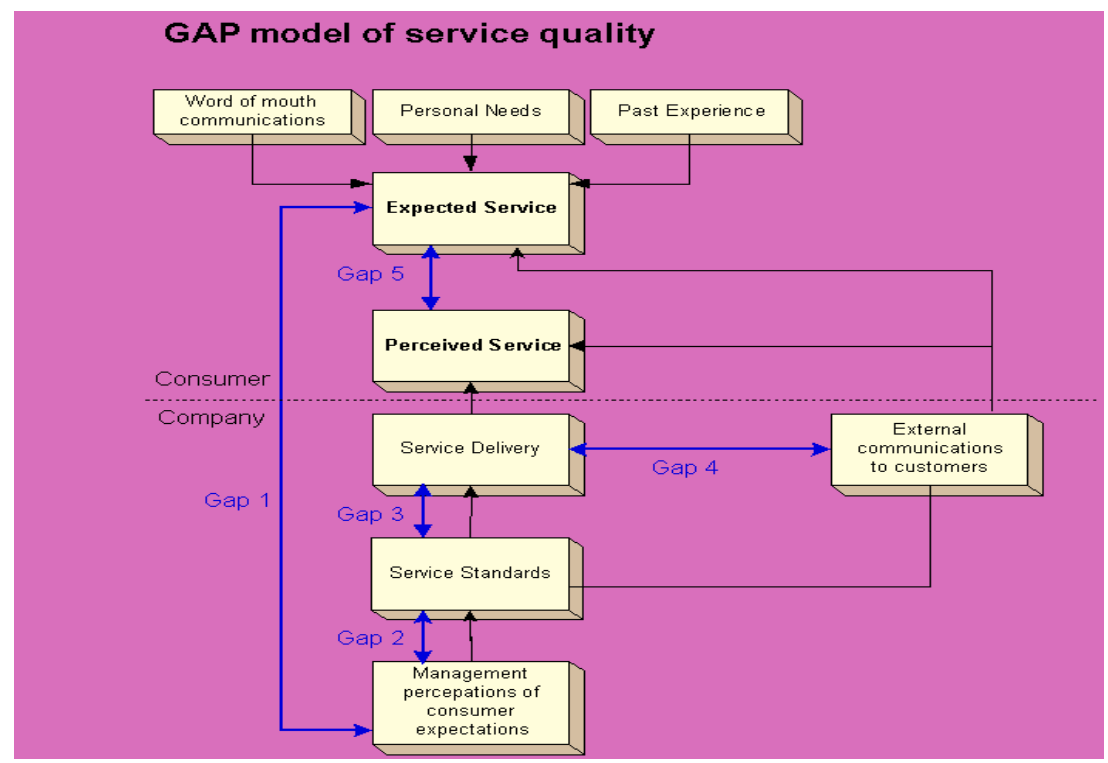

Fig 1. Gap Model of Service Quality

According to the figure 1, five gaps were identified which led to unsuccessful services: (i) gap between consumer expectation and management perception. The gap arises, because management is not fully aware of what problems consumers want; (ii) gap between management perception and service quality specifications. Gaps arise, because management's understanding of the desires of consumers is good, but in fact management is not fully able to provide services that consumers want; (iii) gap between service quality specifications and service delivery. This gap arises, because the quality of service specifically is good, but because employees who provide services are poorly trained, new, and rigid, so the way to provide services is less good and less than perfect; (iv) gap between service delivery and external communications. This gap arises, due to differences between services provided as in service promises written on: advertisements, brochures, or other promotional media. However, the reality given to recipients of services is not in accordance with what they receive; and (v) gap between perceived service and expected service. This gap arises, because the service received by the recipient of the service is not in accordance with what he imagined or expected the recipient of the service.

\section{Health Services of $\mathrm{CHC}$}

The health services of $\mathrm{CHC}$ or $\mathrm{CHC}$ services are one form of public service that must be provided by the government itself or provided jointly between the government and the community. CHC services are important nowadays, at least that in order to improve health services, it is necessary to answer the gap in services provided by CHC with services that are the hope of the community as recipients of services.

The results of a study carried out by [8] that in 2002 Govermance and Decentralization (GDS) in 20 provinces in Indonesia showed that the performance of public services in the implementation of decentralization has not been able to answer the criteria of quality service . Whereas "the implementation of regional autonomy does not exacerbate the quality of public services but in general the practice of public service delivery is still far from the principles of good governance". 
In the current development, there are several trends and strengths in the external environment to influence the health service system implemented by $\mathrm{CHC}$ [9], namely:

1. CHC users in the US are expected to double from 20 to 40 million users after access to health care is increased to 50 million by 2025.[10 ]

2. Pressure on health care costs will likely continue to increase. The cost of replacing medicines will be the same as treatment in all states in America for 2013 and 2014,

3. Affordable regulatory care provisions in the United States will expand Accountable Care Organizations (ACOs) to create a greater focus on the health of the population, through the CHC .

4. Growth in the number of communities requires efforts to build community resilience in various fields (for example, food, economy and energy), especially health (Official Transition Initiatives, 2012)

5. There is growing public conversation about the need for justice or equality in society, and this conversation tends to grow because economic conditions deteriorate, more jobs are lost, and unemployment continues. There is parallel recognition that health equality needs to be addressed through health care reform. A recent poll shows that citizens pay attention to this gap, with 78 percent of Americans believing that more action must be taken to ensure that health differences between groups because factors such as education and income no longer exist. Perceived health challenges in the United States (2008).

Understanding such conditions that improving service to $\mathrm{CHC}$ is not only a local need but in line with the conditions and development of health services carried out in developed countries, as well as the need for health services in developing countries, especially in responding to the various needs that are developing at this time.

\section{Local Wisdom}

In principle, "local wisdom" is not an effort developed by scientists to plant national, international, or global policies, but it will be very helpful to develop culture, which develops in certain communities. Local wisdom at the level of local culture which is regularly carried out to manage social institutions in community life. Thus to develop local wisdom, we need to adjust various cultural values and traditions that exist. Sibirani needs to know that wisdom, reliability, the world have the essence of the basic values of cultural traditions and provide functions for the implementation or existence of humans [11]. The functions of local wisdom are: (i) conservation and preservation of natural resources; (ii) human resource development; (iii) the development of culture and science; (iv) advice, trust, literature and abstinence; (v) social meaning such as communal/kinship integration ceremonies; (vi) means ethics and morals; and (vii) meaning politically, for example the bowling ceremony and the patron of the client. Local wisdom is the ability to absorb foreign cultures that come selectively, meaning that they are adapted to the local atmosphere [12]. Such things are the characteristics of an area. Local Wisdom has several characteristics, namely (i) having the ability to control; (ii) is a stronghold to survive external cultural influences; (iii) having the ability to accommodate outside culture has the ability to provide direction for cultural development; and (iv) has the ability to integrate or integrate external cultures and indigenous cultures. 


\section{Method}

This study aims to: (i) identify services provided to NHI program patients at three CHC in three Regencies / Cities in East Java; (ii) analyze and map the services provided to NHI program patients at three CHC in three Regencies / Cities in East Java; (iii) analyzing NHI program patient service models at three CHC in three Regencies / Cities in East Java; and (iv) formulating a draft NHI program patient service model at three CHC in three Regencies / Cities in East Java based on local wisdom. The study was carried out in CHC in three Regencies / Cities, namely: Medokan Ayu CHC, Rungkut Sub-District, Surabaya City; North Ponorogo CHC, Ponorogo District; and Batu CHC, Batu City District, Batu. Research approach to explorative qualitative approach. Research instruments: researchers themselves, interviews, and observations. Data analysis techniques using the Interactive Model perspective [13].

\section{Discussion}

According to the results of the study, the model of health services carried out by three $\mathrm{CHC}$ that were the location of the study could be described and analyzed with qualitative approaches as follows:

\section{CHC Health Service \\ 1. 1. Health Services in North Ponorogo CHC}

That North Ponorogo CHC has local wisdom that can be developed in service to patients for both general patients and NHI. This CHC has patients who are very loyal primarily for dental and oral examinations since 1954 and immunizations. Several innovations have been made to provide maximum service to patients. Among them are "immunization center, and integrated pregnancy services". The implementation of this innovation statement is that there are several patients coming to get services including services to mothers and children (babies). This CHC has collaborated with several schools in its work area to immunize hepatitis, diphtheria and others. Including students who do not take immunizations at school, can follow immunization at the $\mathrm{CHC}$.

Analysis that can be given by researchers that this $\mathrm{CHC}$ is in addition to working with school institutions, actually services that are based on local wisdom can be developed to carry out service innovations. Thus, the services provided will create a constant congeniality visiting the $\mathrm{CHC}$ for immunization, including dental and oral examinations that are superior in service. Health services that are based on local wisdom can be developed by combining with a culture that is a peculiarity of Ponorogo as the City of Reog. Thus, the outside services of the CHC can present a small amount of immunization events so that the children who attend can seek treatment or get health care while enjoying reog entertainment.

Services based on local wisdom also deserve to be developed in other areas, especially in villages that get the title of "idiot village". The village in Karangpatihan Village, Balong Subdistrict, when the study was conducted, there were 99 people who were mentally retarded. This data is a concern for CHC services based on local wisdom. This North Ponorogo CHC is a CHC located in the center of the city which is the "referral" of patients from various parts of the District in Ponorogo Regency. In addition, the location of the CHC close to the referral hospital is also a factor in the number of pesien who seek treatment at the North Ponorogo CHC. In connection with these data according to researchers, if North Ponorogo CHC is right to 
initiate to become a CHC that makes health service innovations that focus on mental health services. Here are the local wisdom matrix recommended by researchers in developing the North Ponorogo CHC service model (see Table 1).

Table 1. Local Wisdom Recommended by Researchers in Developing NHI Patient Services at North Ponorogo CHC

\begin{tabular}{|l|l|}
\hline Local Wisdom & $\begin{array}{l}\text { Recommendations for CHC Health Service } \\
\text { Development }\end{array}$ \\
\hline $\begin{array}{l}\text { Community loyalty for generations to carry } \\
\text { out immunizations at the CHC. }\end{array}$ & $\begin{array}{l}\text { Presenting mini reog at immunization events. } \\
\text { Both done at the CHC and at school. }\end{array}$ \\
\hline $\begin{array}{l}\text { Collaboration with schools to carry out } \\
\text { immunizations that have been carried out for } \\
\text { decades. }\end{array}$ & $\begin{array}{l}\text { Presenting children's competitions that are fun } \\
\text { and game on immunization events }\end{array}$ \\
\hline $\begin{array}{l}\text { Since 1954 it has become a "reference" for } \\
\text { dental examinations. }\end{array}$ & Integrated Dental Center \\
\hline $\begin{array}{l}\text { Many and loyal Health Cadres both Toddler } \\
\text { "Posyandu" and Elderly }\end{array}$ & $\begin{array}{l}\text { Many and loyal Health Cadres both Toddler } \\
\text { "Posyandu" and Elderly }\end{array}$ \\
\hline Idiot village predicate & The mental health service program \\
\hline
\end{tabular}

Source: research data processed, 2018

\subsection{Health Services at Medokan Ayu CHC}

Medokan Ayu CHC is a CHC located in East Surabaya City. This CHC is relatively advanced, because it is equipped with: ER, Inpatient, and Other services. In addition, services at Medokan Ayu CHC are IT-based, ranging from queues, counters, poly to pharmacy or medicine. However, SIMPUS (CHC Management Information System) has not been effective, due to labor shortages in the drug depot. Supposedly, patients from poly immediately take drugs at the Pharmacy Depo do not need to use the recipe again.

Local wisdom that needs to be developed by Medokan Ayu CHC by looking at the population data in its area is widely distributed at ages 5-9 years, 10-14 years, 15-49 years, 4549 years. This age includes school age and productive age. In addition, the existence of Medokan Ayu CHC is located in Metropolis City, of course there is a very strong heterogeneous environmental influence compared to $\mathrm{CHC}$ in the suburbs. However, according to researchers, there is still a need to develop specific services for adolescents and for the population of productive age.

Medokan Ayu CHC, according to the results of the study, showed that the CHC became a place for student internships from: Airlangga University, Stikes, Hang Tuah University, Surabaya University, especially in nursing, midwives, and pharmacies. With many students from various universities, this has a positive impact on the development of this institution. However, the existence of apprenticeship students has not been used optimally, such as: conducting counseling, education about health for adolescents and mothers of productive age.

Other local wisdoms are research attention, including the loyalty of "Posyandu" Cadres who have been helping programs related to community service. Awards from "Posyandu" cadres included: (i) Mrs. Sudarwati, the Wonorejo cadre representative, won the first example 
of the Surabaya City "Posyandu" cadre in 2010; Mrs. Ira Prihandini, cadre of RW VI, Medokan Ayu Village, won the title of the 2012 Surabaya City Exemplary Posyandu cadre (see Table 2).

Table 2. Local Wisdom Recommended by Researchers in Developing NHI Patient Services at Medokan Ayu CHC

\begin{tabular}{|l|l|}
\hline Local Wisdom & $\begin{array}{l}\text { Recommendations for CHC Health Service } \\
\text { Development }\end{array}$ \\
\hline $\begin{array}{l}\text { Have a population that is distributed to } \\
\text { school age and productive age }\end{array}$ & $\begin{array}{l}\text { Develop services for adolescents and mothers of } \\
\text { productive age by collaborating with cross- } \\
\text { sectors. For example: Police, National Narcotics } \\
\text { Agency, Social Service and Health Service. }\end{array}$ \\
\hline $\begin{array}{l}\text { Close to state universities and health } \\
\text { schools both at the same level as } \\
\text { vocational schools and high schools }\end{array}$ & $\begin{array}{l}\text { Maximizing partnerships / partnerships with } \\
\text { universities or equivalent and the School of } \\
\text { Health to support community services. }\end{array}$ \\
\hline $\begin{array}{l}\text { Health Cadres are loyal and have a } \\
\text { high commitment to Toddler and } \\
\text { Elderly "Posyandu" }\end{array}$ & $\begin{array}{l}\text { Maximizing cadre competence by following } \\
\text { various kinds of health training / counseling }\end{array}$ \\
\hline
\end{tabular}

Source: research data processed, 2018

\subsection{Health Services at Batu CHC}

Local wisdom that is feasible to develop and become an innovation development for NHI patient service development is the CHC tourism emergency room. This is because that Batu City has various types of tourism, such as: Angkot Museum, Jatim Park 2, BNS (Batu Night Spectacular), Eco Green Park, Coban Rondo, Selecta Park, and others. At present, the CHC tourism emergency room serves all patients who are heading to Batu City. The CHC tourism emergency room also has the flexibility to be able to go to the hospital, and provide comfort for tourists.

The results showed that the visit of many NHI patients who visited were aged 45-69 years or entered in the elderly. An analysis can be given that local wisdom is a consideration for developing services, especially services for the elderly or elderly center. This service begins with the absence of queues for elderly patients both at counters and drug depots, public facilities such as squatting closets, handrails when riding, comfortable chairs and so on.

Local wisdom that needs to be developed by Batu $\mathrm{CHC}$ by looking at the population data in its area is widely distributed evenly among Toddlers (0-4) up to the age of 45-69 years. This age includes school age and productive age. The most appropriate service development service innovation is for children and teenagers of school age. The thing that is taken into consideration is the predicate of City of Tourism, assumed to be very vulnerable to outside influences. Therefore, adolescents really need a strong mental foundation so as not to fall into unwanted free association.

Table 3. Local Wisdom Recommended by Researchers in Developing NHI Patient Services at Batu CHC

\begin{tabular}{|l|l|}
\hline Local Wisdom & $\begin{array}{l}\text { Recommendations for CHC Health Service } \\
\text { Development }\end{array}$ \\
\hline Batu as a city of tourism & $\begin{array}{l}\text { Developing a "tourism ER" service. Serving all } \\
\text { of the main NHI patients who experience health } \\
\text { problems while recreation to Batu City. }\end{array}$ \\
\hline
\end{tabular}




\begin{tabular}{|l|l|}
\hline Local Wisdom & $\begin{array}{l}\text { Recommendations for CHC Health Service } \\
\text { Development }\end{array}$ \\
\hline $\begin{array}{l}\text { JKN patients who visit are aged 45-69 } \\
\text { years or enter the elderly }\end{array}$ & Elderly Center services are developed \\
\hline $\begin{array}{l}\text { Have a distributed population at } \\
\text { school age }\end{array}$ & $\begin{array}{l}\text { Develop services for adolescents in collaboration } \\
\text { with cross-sectors. For example: Police, National } \\
\text { Narcotics Agency, Social Service and Health } \\
\text { Service. }\end{array}$ \\
\hline
\end{tabular}

Source: research data processed, 2018

\section{Model of CHC Health Services}

CHC health services in the three CHC that are the research sites show different characteristics, at least these differences can be divided into large classifications, where for Ponorogo $\mathrm{CHC}$, and Batu $\mathrm{CHC}$, it is more focused on providing services within the $\mathrm{CHC}$ building, while for Medokan Ayu CHC, holding service inside and outside the $\mathrm{CHC}$ building. Judging from the aspect of service variation, there are also various data. The health care model implemented as described above shows the level of variation in health services that differ between health centers that are the place of research.

Referring to the various types of health services carried out by each health center that is the place of research, the following models in Figure 2 can be formulated:

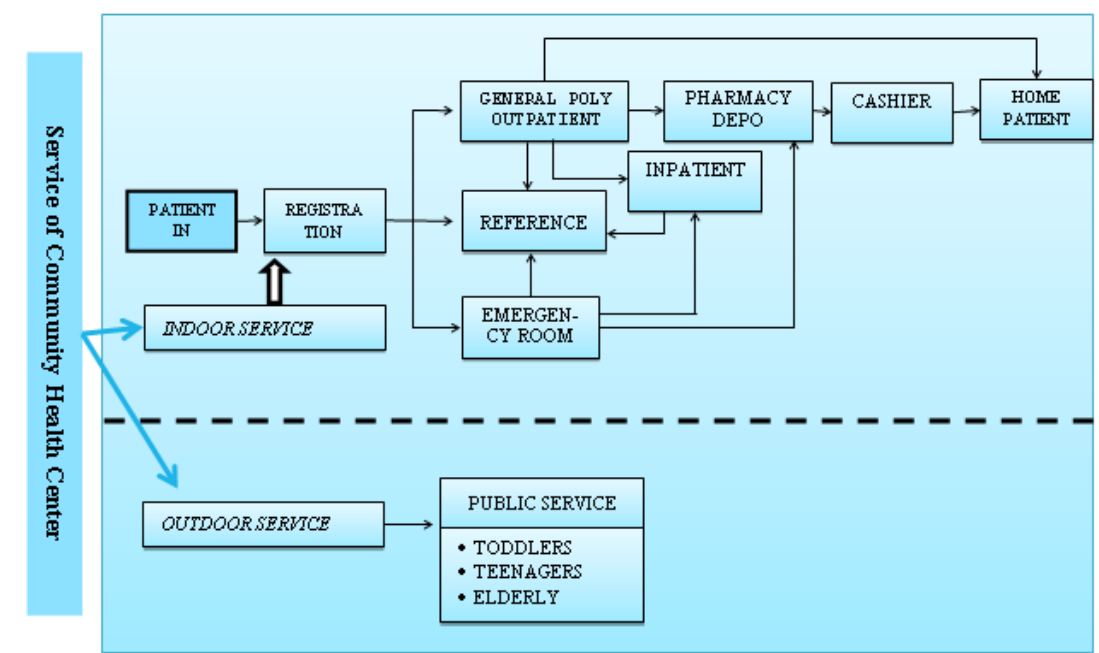

Fig 2. Model of Conventional Health Services of CHC

Based on the figure 2, the health patient service flow can be divided into two parts, namely:

1. Patient Health Services carried out inside the building, with the following channels:

a. Registration:

1) Patients come to the patient registration site, take the registration queue number in the queue machine

2) Patients are called according to the queue serial number.

3) The patient shows an identity card (Population Card/ Family Card, or Health Insurance Card) that they have or a medical card if they have ever checked in the $\mathrm{CHC}$ to the registration officer for registration. 
4) The registration officer submits the check queue number in the intended destination. b. Patients see General Poly:

1) Medical officers (doctors, midwives, nurses) carry out examinations of patients.

2) Medical officers refer patients to related units (laboratories, consultation clinics or other units) if needed.

3) The medical officer makes a prescription and is handed over to the patient.

4) The patient goes to the cashier to complete administration.

5) The cashier submits details of the cost of services to the patient and asks to wait for the results of the drug in the waiting room or directs to the administration if it requires a letter number and $\mathrm{CHC}$ stamp.

6) Medicinal officers give drugs to patients.

7) Patients go home.

c. Patients take a referral to hospitalize in the referred Hospital

d. Patients go to ER:

1) referral for hospitalization

2) take drugs to the pharmacy depo

3) hospitalization in referred Hospital

2. Services carried out outside the building are services provided by $\mathrm{CHC}$, which aim to motivate and encourage the community to live a healthy life. This service is aimed at the community around the $\mathrm{CHC}$, especially in groups: Toddlers, Teens and the Elderly.

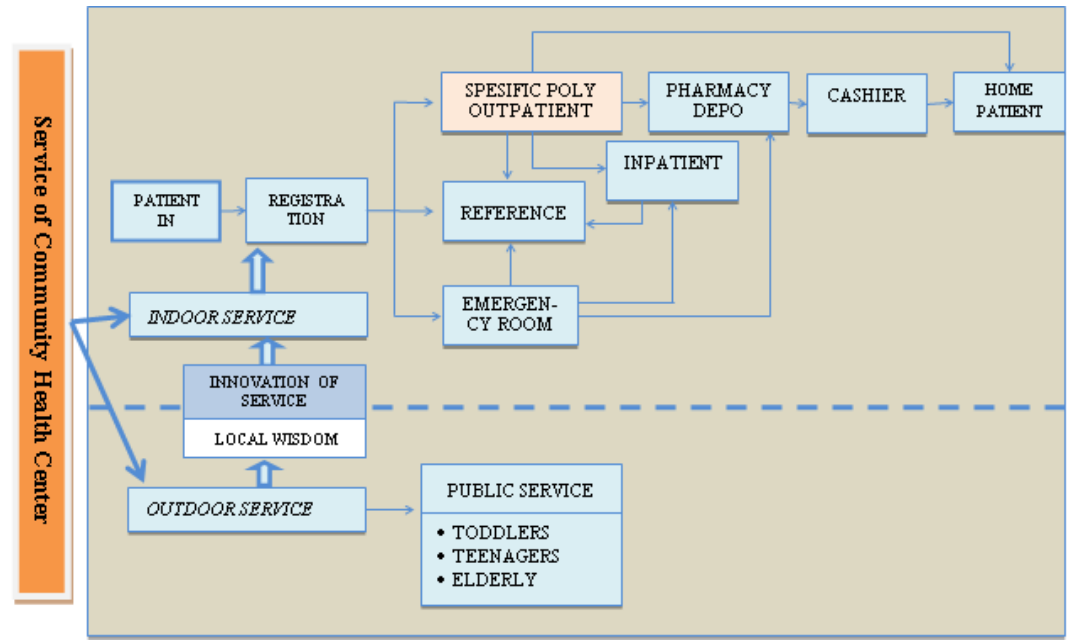

Fig 3. Model of CHC Services Based on Local Wisdom

Based on the figure 3 , the health patient service flow can also be divided into two parts, namely:

1.Patient Health Services carried out inside the building, with the following channels:

a. Registration:

1) Patients come to the patient registration site, take the registration queue number in the queue machine

2) Patients are called according to the queue serial number. 
3) The patient shows an identity card (Population Card/ Family Card, or Health Insurance Card) that they have or a medical card if they have ever checked in the $\mathrm{CHC}$ to the registration officer for registration.

4) The registration officer submits the check queue number in the intended destination. b. Patients waiting in the top service poles provided by the $\mathrm{CHC}$ :

1) Medical officers (doctors, midwives, nurses) carry out examinations of patients.

2) Medical officers refer patients to related units (laboratories, consultation clinics or other units) if needed.

3) The medical officer makes a prescription and is handed over to the patient.

4) The patient goes to the cashier to complete administration.

5) The cashier submits details of the cost of services to the patient and asks to wait for the results of the drug in the waiting room or directs to the administration if it requires a letter number and $\mathrm{CHC}$ stamp.

6) Medicinal officers give drugs to patients.

7) Patients go home.

c. Patients take a referral to hospitalize in the referred Hospital

d. Patients go to ER:

1) referral for hospitalization

2) take drugs to the pharmacy depo

3) hospitalization in referred Hospital

2. Services carried out outside the building are services provided by $\mathrm{CHC}$, which aim to motivate and encourage the community to live a healthy life. Excellent service to the community, grouped into:

a. Services for toddlers, healthy program services for toddlers, such as presenting children's competitions that are fun and game on immunization events, maximizing cadre competencies by participating in various health training / counseling.

b. Services for Adolescents, healthy program services for adolescents, such as developing services for adolescents in collaboration with cross-sectors. For example: Police, BNN, Social Service and Health Service.

c. Services for the elderly, healthy program services for the elderly, such as developing elderly services or the elderly center.

\section{Conclusion}

The conclusions of this study are: (i) the service model for the current NHI program is still based on all types of diseases suffered by patients without being based on priority scale, because of the limited medical personnel and infrastructure needed, so impressed slow; (ii) NHI program service innovation at Medokan Ayu CHC Surabaya is still limited to the electronicbased registration system (e-health), but patients cannot use it optimally due to limited ability. On the other hand, health services are still using conventional models; and (iii) to improve the health services of the NHI program implemented by health centers in East Java, it is necessary to innovate service development models that pay attention to local wisdom and the needs of the surrounding community.

Acknowledgements. The authors would like to thank the reviewers, especially to Universitas Muhammadiyah Sidoarjo (UMSIDA) that hold the International Conference on Emerging Media, and Social Science December 7-8, 2018 Banyuwangi, Indonesia. 


\section{References}

[1 ] S. Qhisti, "Kebijakan dan Manajemen Publik, Pelaksanaan Program Jaminan Kesehatan Nasional (JKN) Dalam Peningkatan Kualitas Pelayanan Kesehatan Di RSU Haji Surabaya”, Jurnal Universitas Airlangga, Volume 3, Nomor 2, ISSN 2303 - 341X, (2015).

[2] Kulo Debby, R., Massie G. A., dan Kandou G. D., Pengelolaan dan Pemanfaatan Dana Yang Berasal Dari Program Jaminan Kesehatan Nasional di RSUD Datoe Binangkang Kabupaten Bolaang Mongondow, Jurnal JIKMU Fakultas Kedokteran Universitas Sam Ratulangi Manado, Vol.4, No.4, (2014).

[3] Pramono, Sapto and Roekminiati, Sri, "Implementasi Kebijakan Program Jaminan Kesehatan Nasional (JKN) Pada Puskesmas Sebagai Fasilitas Kesehatan Tingkat Pertama (FKTP), Penelitian DIPA- Universitas Dr. Soetomo, (2015)

[4] Denhardt, Janer V. and Denhardt, Robert B., The New Public Service: Serving Not Steering, Armonk, N.Y : M.E.Sharpe, (2003).

[5] Frank, Sue A and Lewis, Gregory B., "Government Employees: Working Hard or Hardly Working?". The American Review of Public Administration, Sage Publications, Vol. 34, No.1, page 36-51, doi:10.1177/0275074003258823 (2004).

[6] Volokh, Sasha. "Are public-sector employees "overpaid"?". The Washington Post. 7 February (2014)

[7] Shahin, Aras, "Servqual and Model of Service Quality Gaps: A Framework for Determining and Prioritizing Critical Factors in Delivering Quality Services", the ICFAI University Press, India, (2006)

[8] Pasolong, Harbani, Kepemimpinan Birokrasi, CV. ALFABETA (2013)

[9] Community Health Centers Leveraging the Social Determinants of Health Report, a project of the Institute for Alternative Futures supported by a grant from the Kresge Foundation, (2012)

[10] Institute for Alternative Futures. "Primary Care 2025: A Scenario Exploration", pp. 19. January (2012)

[11] Sibirani, Robert, The role of local wisdom in developing friendly city, OP Conf. Series: Earth and Environmental Science126 (2018) 012094 doi:10.1088/1755-1315/126/1/012094, https://www.researchgate.net/publication/323822641

[12] Atmodjo, Pengertian Kearifan Lokal dan Relevansinya dalam Moderniasi, Jakarta，Dunia Putaka (1986)

[13] Miles, Matthew B., Huberman, A. Michael, and Saldaña, Johnny, Qualitative Data Analysis: A Methods Sourcebook, Third edition, Sage Publications. (2014),infographic/208527. [Accessed: 02-Aug-2018]. 